\title{
COVID-19, Islam and Christianity
}

\section{Lindsay B. Carey ${ }^{1}$ · Jeffery Cohen ${ }^{2} \cdot$ Harold G. Koenig ${ }^{3,4,5} \cdot$ Ezra Gabbay $^{6}$}

Accepted: 4 March 2021 / Published online: 13 March 2021

(c) The Author(s), under exclusive licence to Springer Science+Business Media, LLC, part of Springer Nature 2021

\section{Introduction}

Three key topic areas are covered in this second issue of JORH for 2021, namely: (i) COVID-19, (ii) Islam and (iii) Christianity - each topic area reflecting current concerns about health crises challenging religious communities and/or their adherents (JORH, 2021a).

\section{COVID-19}

Following up from the first issue looking at COVID-19 (Hart \& Koenig, 2020) and subsequent issues of JORH, this issue continues to examine the relationship between religion and various aspects of COVID-19. The publication of refereed journal articles from around the world (concerning the biological, psychological, sociological and theological aspects of COVID-19) has been phenomenal. According to

Lindsay B. Carey

Lindsay.Carey@1atrobe.edu.au

Jeffery Cohen

jeffrey.cohen@nd.edu.au

Harold G. Koenig

Harold.Koenig@duke.edu

Ezra Gabbay

ezg9002@med.cornell.edu

1 Public Health Palliative Care Unit, La Trobe University, Melbourne, Australia

2 School of Medicine (Sydney), University of Notre Dame Australia; St Vincent's Private Hospital Sydney, New South Wales, Australia

3 Department of Psychiatry and Behavioral Sciences, Duke University Health Systems, Durham, NC, USA

4 Department of Medicine, Duke University Health Systems, Durham, NC, USA

5 Department of Medicine, King Abdulaziz University, Jeddah, Saudi Arabia

6 Division of General Internal Medicine, Department of Medicine, Hospital Medicine Section, Weill Cornell Medicine, New York, NY, USA 
SCOPUS, an average of 10,000 articles per month from July 2020 were being published regarding the impact of COVID-19 (Carey, 2021; Goyal, 2021). The JORH has thus far contributed only twenty-five articles, but this is far more than similar journals.

Within this issue, we consider the devastating effect of COVID-19 upon the Christian pilgrimages to Santiago de Compostela (Spain), Lourdes (France) and those in Poland, namely Czestochowa, Krakow-Lagiewniki and Wadawice. Prior to COVID-19 registered pilgrims totaled nearly 12 million to Catholic shrines across Europe but these decreased during the first six months by $90-95 \%$. There was a corresponding decrease in those aged $60+$ who managed to complete pilgrimages - however, it is noted there was an increase in local pilgrimages led by the 'Caminoholics.'

For those unable to exercise during COVID-19, one consideration has been the likelihood of unhealthy weight gain and obesity because of confinement, lack of activity and stress - sometimes referred to as 'COVID Belly.' A submission on religious coping and weight change among the Orthodox Jewish community indicates that religious observance may actually moderate the relationship between stress and weight gain during times of crisis (i.e., there was little or no weight gain among those scoring higher on intrinsic religiosity). Finally, those of the Hindu faith present the four conceptual 'D's of the Bhagavad Gita as a psychological support for concurrently resolving moral injury, ethical dilemmas and COVID-19: (i) Detachment,' (ii) 'Doer and the concept of Self,' (iii) 'Dharma or Duty' and (iv) 'Dhyana or Meditation.'

\section{Islam}

There are those who proudly proclaim that, despite the suffering experienced by many Muslims throughout the world, Islam is the 'greatest religion.' What is certain, is that due to global trends of increased birth rates among Muslims, increased evangelicalism and migration, Islam is the fastest-growing religion in the world. In fact, it is projected that after 2060, Islam will become the religion with the most followers (PRC, 2017; Table 1). It can also be argued that the decline of Christianity (due to lower birth rates, aging members and increased death rates), combined with the increase in secularist, humanist and atheist ideology among the Western younger generation (who prefer 'spirituality' to organized religion), will further contribute to Islam's increasing role as a world religion.

What is also evident, however, based on the research presented in this JORH issue, is that adherents of Islam, like adherents of all other religions, struggle with, and nobly attempt to deal with, multiple and challenging health-care issues that affect the well-being of Muslims. Health concerns addressed in this issue (JORH, 2021) include stress among Muslim high-school students, psychological maltreatment among college adults, cardiovascular disease, stress among family caregivers of intensive care patients, and stroke victims, organ transplantation, osteoarthritis, mental delirium, discrimination and psychological distress, and finally death anxiety. Irrespective of one's religious beliefs, it would seem that all faiths have in 
Table 1 The Changing Global Religious Landscape: 2015-2060. Source Adapted from the Pew Research Center Demographic Projections (refer PRC, 2017 for additional detail)

\begin{tabular}{llllll}
\hline Religious Belief & 2015 Population & $\begin{array}{l}\% \text { World } \\
\text { Population } \\
2015\end{array}$ & $\begin{array}{l}\text { Projected 2060 } \\
\text { Population }\end{array}$ & $\begin{array}{l}\text { \% World } \\
\text { Population } \\
2060\end{array}$ & $\begin{array}{l}\text { Population } \\
\text { Growth } \\
2015-2060\end{array}$ \\
\hline Christians & $2,276,250,000$ & $31.2 \%$ & $3,054,460,000$ & 31.8 & $778,210,000$ \\
Muslims & $1,752,620,000$ & 24.1 & $2,987,390,000$ & 31.1 & $1,234,770,000$ \\
Unaffiliated & $1,165,020,000$ & 16.0 & $1,202,300,000$ & 12.5 & $37,280,000$ \\
Hindus & $1,099,110,000$ & 15.1 & $1,392,900,000$ & 14.5 & $293,790,000$ \\
Buddhists & $499,380,000$ & 6.9 & $461,980,000$ & 4.8 & $-37,400,000$ \\
Folk Religions & $418,280,000$ & 5.7 & $440,950,000$ & 4.6 & $22,670,000$ \\
Other Religions & $59,710,000$ & 0.8 & $59,410,000$ & 0.6 & $-300,000$ \\
Jews & $14,270,000$ & 0.2 & $16,370,000$ & 0.2 & $2,100,000$ \\
Total & $7,284,640,000$ & 100.00 & $9,615,760,000$ & 100.0 & $2,331,120,000$ \\
\hline
\end{tabular}

The Pew Research Center is a charitable nonpartisan information service which does not subscribe to any political or religious policy positions

common, adherents with various incapacitating health and medical conditions, an understanding of the fragility of life, and a desire to find strategies for coping with, and resolving, these challenges.

\section{Christianity}

Similar to the variety of challenges faced by Islamic adherents, within this same issue of JORH a collection of articles has been written from a Christian perspective addressing a wide range of health-related topics. Research in this issue addresses concerns related to religion and body mass index, the needs of African-American churches, child mortality in Brazil, the role of faith-based organizations in addressing the health needs of Latino communities, as well as the beneficial lifestyle practices, experiences and coping strategies of Seventh-Day Adventists. A number of valuable research reviews are also included in this $J O R H$ issue, namely a narrative review of ethnic minority studies for faith-based health promotion, a review of faith community nursing involved in public health interventions, a systematic review regarding the causes, treatments and psychosocial consequences of schizophrenia and depression, an historical review regarding Pope John XXI (philosopher and physician-scientist who died of "crush syndrome," 1277), and finally a qualitative analysis of clergy methods for managing increasingly high-workload demands. 


\section{Coming Issue}

In the next issue, we will be revisiting COVID-19 and covering some additional topics, namely, Judaism, Sex, Women's Health and Medical Education. As noted in the previous editorial, the topic of moral injury (military, civilian and health professionals) has been gaining increasing recognition particularly from a religious/spiritual perspective (Carey \& Hodgson, 2018). Further, this year marks two decades since that devastating event of September 11. Authors are encouraged to contact Dr. Lindsay Carey (Editor in Chief) or Dr. Jeffery Cohen (Associate Editor) if you are considering the topics of moral injury or September 11 for submissions to JORH.

\section{References}

Carey, L. B. (2021). COVID-19, Spiritual Support and Reflective Practice. Health and Social Care Chaplaincy, 9(2), 147-154. https://journals.equinoxpub.com/HSCC/article/view/42733

Carey, L. B., \& Hodgson, T. J. (2018). Chaplaincy, spiritual care and moral injury: Considerations regarding screening and treatment. Frontiers in Psychiatry, 9(619), 1-10. https://doi.org/10.3389/ fpsyt.2018.00619

Goyal, R.D. (2021). COVID-19 Publication Statistics - SCOPUS. Amsterdam, NL: Elsevier (Statistical analysis initiated by L.B. Carey, La Trobe University).

Hart, C., \& Koenig, H. G. (2020). Religion and Health during the COVID-19 pandemic. Journal of Religion and Health, 59(5), 1141-1143. https://doi.org/10.1007/s10943-020-01042-3

JORH. (2021). Journal of Religion and Health, 60(2). New York: Springer Nature. https://link.springer. com/journal/10943/volumes-and-issues/60-2

PRC (2017). 'The Changing Global Religions Landscape'. Pew Research Centre: https://www.pewforum. org/2017/04/05/the-changing-global-religious-landscape/

Publisher's Note Springer Nature remains neutral with regard to jurisdictional claims in published maps and institutional affiliations. 